\title{
A TALE OF TWO SOCIALIST ENTERPRISES: PRODUCTION AND DECISION- MAKING AT ŠKODA AUTO AND AVTOVAZ, 1960-1980
}

\author{
Valentina Fava
}

ESKA | Entreprises et histoire »

2021/2 n 103 | pages 90 à 106

ISSN 1161-2770

ISBN 9782747232258

\section{Article disponible en ligne à l'adresse :}

https://www.cairn.info/revue-entreprises-et-histoire-2021-2-page-90.htm

Distribution électronique Cairn.info pour ESKA.

(c) ESKA. Tous droits réservés pour tous pays.

La reproduction ou représentation de cet article, notamment par photocopie, n'est autorisée que dans les limites des conditions générales d'utilisation du site ou, le cas échéant, des conditions générales de la licence souscrite par votre établissement. Toute autre reproduction ou représentation, en tout ou partie, sous quelque forme et de quelque manière que ce soit, est interdite sauf accord préalable et écrit de l'éditeur, en dehors des cas prévus par la législation en vigueur en France. Il est précisé que son stockage dans une base de données est également interdit. 


\title{
A TALE OF TWO SOCIALIST ENTERPRISES: PRODUCTION AND DECISION-MAKING AT ŠKODA AUTO AND AVTOVAZ, 1960-1980
}

\author{
by Valentina FAVA \\ Assistant Professor of Economic History \\ Department of Management \\ Università Ca' Foscari, Venice
}

Cet article reconstruit les récits organisationnels et techniques qui ont accompagné les étapes stratégiques - la mise en cuvre de nouvelles technologies de véhicules et de process - de l'histoire des usines automobiles Skoda (AZNP) de Mladá Boleslav, en Tchécoslovaquie, et Volga (VAZ) de Togliatti, en Union soviétique, lors de la construction et de la modernisation de ces usines entre les années 1960 et la fin des années 1970. Malgré les similitudes des systèmes macro-économiques et politiques et l'homogénéité structurelle des entreprises communistes, au moins deux trajectoires distinctes peuvent être dégagées pour ces constructeurs automobiles socialistes. Les racines de ces trajectoires proviennent de l'interprétation différente que les experts nationaux avaient donnée, dès les années 1920, aux technologies et aux savoirs managériaux étrangers.

In 1965, while the first Czechoslovak people's car came off the assembly line at the Škoda plant (from 1948 to 1991, AZNP) in Mladá Boleslav, the Soviets signed a contract with the Italian automobile firm Fiat to build the giant VAZ (Volga Automobile Factory, later called AvtoVAZ) in Togliatti (until 1964, Stavropol), on the Volga River. The two factories represented two radically opposed approaches to using foreign technology and technical assistance in automotive production. Because of the unequal division of labour and resources in the Council for Mutual Economic Assistance (CMEA), the
Soviet Union and the Czechoslovak Socialist Republic did not have the same access to foreign technology and expertise or the same financial resources. Nor did their experts and engineers, despite living in socialist countries, share the same attitude to foreign organizational practices and technology. Time did not narrow the gap between the two plants; on the contrary, after the collapse of the Communist regimes in late 1989 and early 1990, the trajectories of the two manufacturers diverged further. Škoda-Auto was quickly integrated into the Volkswagen production networks, becoming a key brand 
of the German group ${ }^{1}$. AvtoVAZ, by contrast, followed a more tortuous route, the result of strong organizational dependency and institutional inertia, which trapped the industry in its "exaggerated Fordism" 2.

Management scholars have satisfactorily demonstrated that the institutional environment played a crucial role in determining the success or failure of the post-socialist transformation of business practices. They have explained the divergent paths of socialist automobile manufacturers by the significant differences both in the post-socialist restructuring of economic and political institutions and in the related quality and characteristics of foreign direct investment ${ }^{3}$. In this article, I argue that the trajectories of the two manufacturers were already divergent under the socialist regimes, despite the similarities in their macroeconomic and political systems (planned economy, state socialism) and the structural homogeneity of the socialist enterprises. The roots of these differences can be traced back to the different interpretation that experts have given since the 1920s to foreign technology and managerial knowledge in motor vehicle manufacturing, an industry that was of great symbolic significance to both socialist modernization and national identity ${ }^{4}$.
To this end, I partly reconstruct the expert narratives that accompanied the key strategic steps - the implementation of new product and process technologies - in the history of the Škoda Auto Plant (AZNP) in Mladá Boleslav and the Volga Automobile Factory (VAZ) in Togliatti in the years between the construction and modernization of their plants in the 1960s and the late 1970s. I also outline an hypothesis that these different translations of foreign managerial and technical knowledge and different organizational identities may well have influenced the post socialist trajectories of the two enterprises ${ }^{5}$.

In each case, the post-1989 economic and political transformation led to a change in ownership and senior management, but both factories remained in operation. As a consequence, the symbiotic relationships between the factory, the enterprise or brand, and local communities initially remained intact, and with it, so did the organizational identities and narratives that local actors had constructed in the previous decades.

The article relies both on travel reports written by engineers and managerial experts during their business trips abroad and on technical documents recording the

\footnotetext{
1 E. Rugraff, "Foreign Direct Investment (FDI) and Supplier-Oriented Upgrading in the Czech Motor Vehicle Industry", Regional Studies, vol. 44, n 2, 2010, p. 627-638 and P. Pavlínek, A Successful Transformation? Restructuring of the Czech Automobile Industry, Heidelberg, Physica-Verlag, 2008.

2 J.-J. Chanaron, "Lada: Viability of Fordism ?", in M. Freyssenet, A. Mair, K. Shimizu, G. Volpato (eds.), One Best Way? Trajectories and Industrial Models of the World's Automobile Producers, Oxford, Oxford University Press, 1998, p. 440-451. See also I. Gurkov and M. J. Morley, "Looking in the rear-view mirror. A 35 year retrospective on the Russian automotive industry", Thunderbird International Business Review, online version, March 2021, p. 1-14 and X. Richet and F. Bourassa, "The Reemergence of the Automotive Industry in Eastern Europe", in C. Von Hirschhausen and J. Bitzer (eds.), The Globalization of Industry and Innovation in Eastern Europe, Cheltenham, UK, Edward Elgar, 2000, p. 59-94.

3 See R. Martin, Transforming Business Systems in Central and Eastern Europe, New York, Oxford University Press, 2013; B. Hancke, M. Rhodes and M. Thatcher, Beyond Varieties of Capitalism: Conflict, Contradiction and Complementarities in the European Economy, Oxford, Oxford University Press, 2007; and N. Bandelj, From Communists to Foreign Capitalists: The Social Foundations of Foreign Direct Investment in Postsocialist Europe, Princeton, Princeton University Press, 2008.

4 On the specific symbolic and national relevance to the car and system of automobility, see T. Edensor, "Automobility and National Identity: Representation, Geography and Driving Practice”, Theory, Culture and Society, vol. 21, $\mathrm{n}^{\circ}$ 4-5, 2004, p. 101-120.

5 For the concept of transfer and organizational narratives, see B. Czarniawska-Joerges and G. Sevón, Global Ideas: How Ideas, Objects and Practices Travel in a Global Economy, Copenhagen, Liber \& Copenhagen Business School Press, 2005, p. 8-10, and B. Czarniawska-Joerges, "Narratives of Individual and Organizational Identities", Annals of the International Communication Association, vol. 17, n 1, 1994, p. 193-221.
} 
decision-making process that accompanied the main changes in product and process technology in the years under analysis. They offer an unusual perspective on the enterprise in state socialism and on the relations between the state, the enterprise and the citizens, since they not only describe factory lay-out, equipment and work organization but also often express technical prowess, professional expectations and, in part, frustrations. In this sense, travel reports can be seen as the material link between the "cultural" and the "material" in the history of both VAZ and Škoda ${ }^{6}$. Concerning Fiat, my archival research was complemented by ten semi-structured interviews I conducted with Fiat experts and managers who took part in the design and construction of the Volga Automobile Plant (2009-2010) ${ }^{7}$. Concerning the Masaryk Academy of Work and Škoda, I relied on secondary sources, my original doctoral thesis (2004) and Tomás Vilímek’s and my further research (2014-2018) ${ }^{8}$.

From a methodological perspective, the use of both company and state archives stems from the need to understand the decision-making process from the local unit of production to the ministries and bodies of the state bureaucracy responsible for the main decisions concerning the national automobile industry ${ }^{9}$. As we will see, the development of this industry had a political and national relevance, and was closely connected to the construction and maintenance of political consent for the regime.

The first part of the essay discusses how focusing on technical narratives might help business historians avoid the dead end that leads them to study the state-owned enterprise as a mere productive plant plagued by the failures of the planned economy's coordination mechanism ${ }^{10}$.

The second section suggests that there were two different paths of development for Comecon automobile manufacturers. One was characterized by reasonably straightforward access to foreign technology and know-how (in the Soviet Union, Poland, Romania). The other forced manufacturers to deal with automotive technology in a piecemeal and more autarchic way (in the German Democratic Republic and Czechoslovakia). The former was the path followed by VAZ at its origins; the latter was followed by Škoda.

The third and final part of the article reconstructs the contacts between Soviet and Czechoslovak automotive experts on the one hand and foreign automotive firms on the other. It does so in three important phases of the Soviet and Czechoslovak automobile industries: in the 1920s and 1930s, when experts from the Soviet Union and Czechoslovakia (not yet socialist) visited the United States of America to learn the principles of scientific management and observe the Fordist revolution; the 1960s and 1970s, when socialist governments heavily borrowed (or intended to borrow) Western technology and know-how to relaunch automobile production as a symbol of socialist material well-being (the Communist Party's grand narrative on socialist technology and consumption) and when the irreformability of the socialist system became evident and the language of global competition permeated the negotiations among socialist and capitalist experts.

\footnotetext{
${ }^{6}$ K. Lipartito, "Connecting the Cultural and the Material in Business History", Enterprise \& Society, vol. 14, n 4 , 2013, p. 686-704.

7 Archivio Storico della Fiat, Turin (Fondo URSS; COMAU; Agnelli; Fiat Allis; Pedrana).

8 Škoda Auto Historical Archives, Mladá Boleslav, Czech Republic.

9 Russian State Archive of the Economy (Rossiiskyi Gosudarstvennyi Arkhiv Ekonomiki (RGAE), Moscow; National Archives of the Czech Republic (Státní ústřední archiv, SÚA), Prague, records from the ÚPV (Úřad předsednictva vlády - Prime Minister's Office), 1954-1959 and 1960-1990.

10 J. Kornai, The Socialist System: The Political Economy of Communism, Princeton, Princeton University Press, 1992.
} 


\section{NARRATIVES, BUSINESS HISTORY ANDTHE SOCIALIST ENTERPRISE}

In 2018, Philip Scranton, in a special issue of Enterprise \& Society, suggested changing perspective and provided a lively account of the evolution of the Communist enterprise in central and Eastern Europe, shedding light on both the twists and turns of the 1960s reform processes and on the agency of socialist managers ${ }^{11}$. In the same issue, Pal Germuska asked business historians a truly provocative question: "What can we learn from the history of communist enterprises?". In what follows here, I try to answer this question by demonstrating that the study of the Communist enterprises not only helps us to better understand society and power under Communist regimes, but it also provides a substantial contribution to the recent methodological debate in business history, offering case studies to observe: (1) the construction and use of the organizational narratives to create a corporate (or political) identity and to justify a current or future strategic choice ${ }^{12},(2)$ the permeability of borders between enterprises and their political and social milieus, (3) the relevance of motives behind managerial choices and, to quote Kenneth Lipartito, the possibility of and need for a "synthesis of the material and the mental in study of the past" 13 .

In 1995, Lipartito wisely suggested that business historians should treat firms as "imagined communities" 14 and leave "functionalism for semiotics" ${ }^{15}$. He invited business historians to reverse the Chandlerian perspective and study how culture informs managerial decision-making and firms' structures. He recommended focusing on the meaning that historical actors in different countries ascribed to technology and to technology's relationship to the context. A few years later, in 2012, Per Hansen cogently argued that business historians should "pay attention not only to contextual and cultural specificity but also to processes of signification and sensemaking and how they matter for decision-making and action" 16 . Triggering an intense debate, Hansen stressed that organizational narratives are relevant to business history since they "are path dependent and constrain actors' choice set by framing the way they perceive the world. Narratives are important factors in constructing organizational culture and identity, creating organizational inertia, path dependence and blind spots. Strong narratives are not easily forgotten" ${ }^{17}$. Since then, organizational narratives have become a popular topic in business history research. They may well be a useful instrument for looking at the history of the Communist enterprise and at

11 P. Scranton, "Managing Communist Enterprises: Poland, Hungary, and Czechoslovakia, 1945-1970", Enterprise \& Society, vol. 19, n 3, 2018, p. 492-537 and P. Germuska, "What Can We Learn from the Business History of Communist Enterprises?”, Enterprise \& Society, vol. 19, n 3, 2018, p. 538-545.

12 D. Wadhwani, R. Suddaby, M. Mordhorst, A. Popp, "History as Organizing: Uses of the Past in Organization Studies", Organization Studies, vol. 39, n 12, 2018, p. 1663-1683; M. Bucheli and D. Wadhwani (eds.), Organizations in Time. History, Theory and Methods, Oxford, Oxford University Press, 2014.

13 K. Lipartito, "Reassembling the Economic: New Departures in Historical Materialism", The American Historical Review, vol. 121, $\mathrm{n}^{\circ} 1,2016$, p. 101.

14 K. Lipartito, "Culture and the Practice of Business History", Business and Economic History, vol. 24, n $2,1995$.

15 P. Hansen, "Business History: A Cultural and Narrative Approach?”, Business History Review, vol. 86, n 4, 2012, p. 693-717, here p. 711. See also P. Scranton and P. Fridenson, Reimagining Business History, Baltimore, Johns Hopkins University Press, 2013.

16 P. Hansen, "Business History...”, art. cit., p. 712.

17 P. Hansen, "Business History...", art. cit., p. 700 and the contributions of A. Popp, "Making Choices in Time", Enterprise \& Society, vol. 14, n 3, 2013, p. 467-474 and D. Raff, "How to Do Things with Time", Enterprise \& Society, vol. 14, n³, 2013, p. 435-466. 
its post-1989 transformation ${ }^{18}$. An approach based on narratives offers business historians a methodological way out of the functionalist dead end, which has long hindered research on Communist enterprises. In fact, business historians have long seen the Communist enterprise as a mere production unit, whose directors could not make strategic decisions concerning production, management or distribution ${ }^{19}$. When looking at Communist enterprises, business historians occasionally used to concentrate on the frame in which these enterprises operated - the planned economy and its dysfunctions ${ }^{20}$. They have, however, neglected conflicts and negotiations which took place in the industrial hierarchy, often setting technical experts and managers in opposition to each other and not necessarily influencing decision-making. Business history has failed to see the way in which different actors, at the different levels of the planning hierarchy, constructed and negotiated their room for manoeuvre. The prevailing functionalist approach has not priced the subjective motives that are behind individual actors' actions and the micro processes of power, making these actors appear as a faceless and soulless bureaucracy solely in the Party's service $^{21}$.
Another peculiarity of the Communist enterprise, which business historians underestimate, is the overlapping of its political, welfare and production functions as well as the pervasiveness of informal networks and behaviours ${ }^{22}$. The factory was indeed the heart of the Party's exercise of power and control over society and construction of consensus. The production function cannot be isolated from the political function of the enterprise ${ }^{23}$. In the socialist system, especially from the 1960s on, the central plan was used by the Party more as a "mobilizing vision" than as an "attempt to achieve a rational allocation of resources" 24 .

Technical partnerships with Western companies created opportunities for technical experts, from both capitalist and socialist Europe, to discuss and confront each other. Factory floors and state research institutes became laboratories in which to discuss input from the West, and to transform it. In these laboratories, discussions about the material aspects of production and technology often provided experts with an opportunity to share their experiences and expectations, to express concepts or thoughts related to their national and professional identities and to the meaning they attached to industrial modernization,

18 D. Ravasi and K. Schreiter, "Institutional Pressures and Organizational Identity: The Case of Deutsche Werkstätten Hellerau in the GDR and Beyond, 1945-1996", Business History Review, vol. 92, n 3, 2018, p. 453-481.

19 A. D. Chandler, Jr., "Organizational Capabilities and the Economic History of the Industrial Enterprise", Journal of Economic Perspectives, vol. 6, $\mathrm{n}^{\circ} 3$, 1992, p. 84-85 and F. Amatori and A. Colli, Business History: Complexities and Comparisons, London-New York, Routledge, 2011, p. 161-170.

${ }^{20}$ M. Kragh, "The Soviet Enterprise: What Have We Learned from the Archives?", Enterprise \& Society, vol. 14, $\mathrm{n}^{\circ} 2,2013$, p. 360-394.

21 The "micro-stories told by managers and others as they interact and go about their daily work": C. Fenton and A. Langley, "Strategy as Practice and the Narrative Turn”, Organization Studies, vol. 32, n 9, 2011, p. 1172 and 1175 ; specifically on post-socialism, A. Soulsby and E. Clark, "Organization Theory and the Post-Socialist Transformation: Contributions to Organizational Knowledge”, Human Relations, vol. 60, n 10, 2007, p. 1419-1442, here p. 1423.

22 J. Morris and S. Hinz, "From 'Avtoritet' and Autonomy to Self-Exploitation in the Russian Automotive Industry", in C. Hann and J. Parry (eds.), Industrial Labor on the Margins of Capitalism: Precarity, Class, and the Neoliberal Subject, Oxford-New York, Berghahn Books, 2018: "many monotown enterprises acted almost as 'total social institutions' and 'States within States", p. 244.

23 A. Lüdtke (ed.), Histoire du quotidien, Paris, Éditions de la MSH, 1994, and A. Lüdtke, "La domination comme pratique sociale", Sociétés contemporaines, n 99-100, 2015, p. 17-63. See also S. Kott, "Pour une histoire sociale du pouvoir en Europe communiste : introduction thématique", Revue d 'histoire moderne et contemporaine, vol. 49, $\mathrm{n}^{\circ} 2$, 2002, p. 5-23 and T. Lindenberger, Herrschaft und Eigen-Sinn in der Diktatur: Studien zur Gesellschaftsgeschichte $\operatorname{der} D D R$, Cologne-Weimar, Böhlau, 1999.

24 S. Clarke, The Russian Enterprise in Transition: Case Studies, Cheltenham, Edward Elgar, 1996, p.14. 
foreign knowledge and production innovation. These narratives are valuable sources for historians, not only for reconstructing the decisions taken and evaluating their technical rationality, and how problems were faced and solved by technical and managerial experts, but also for understanding how decisions, often taken elsewhere, were made sense of ${ }^{25}$. It is thus useful to explore the coherence (or lack thereof) that these narratives had over time.

And yet this approach raises some methodological caveats. The first and more obvious one is the accessibility of sources, their scarcity and their random, miscellaneous character. The second concerns the choice of narratives and the quality and risks inherent in the use of this specific type of source in the socialist context. In particular, problems may follow from the predominance of a normalizing, official, Marxist-Leninist narrative aiming at expressing Party control. This pervades most official documents. Nonetheless, although the voice of the Party was considerably louder than the others, one should also look for competing narratives, which local and foreign experts cultivated and left behind. They of course need to be analysed as critically as possible and crosschecked against other material and sources.

\section{TWO DIFFERENT PATHS FOR COMECON AUTOMOBILE MANUFACTURERS}

In the last decade, much historical research has focused on socialist motorization and automotive production in CMEA countries. Most of this work considers the political and cultural impact of the diffusion of the motor car in socialist regimes and looks at the dysfunctions of the mass production of consumer goods in planned economies. Though planners saw motorization and individual mobility as a not entirely welcome by-product of car production, the car was to become a symbol of socialist modernity and the car factory a locus on which to build consent for the Party, both nourishing visions of socialist prosperity and well-being ${ }^{26}$. Paradoxically, in most socialist regimes, the car never ceased to be a symbol of national achievement and each of the many CMEA people's cars were the result of the appropriation and co-manufacture of foreign technologies and they had a national character.

In fact, not all CMEA countries could rely on foreign technology to build or rebuild their automotive plants. During the 1960s, when automobile production was again high on planners' agendas in most socialist countries, two options were generally available: (1) intra-CMEA cooperation agreements based on cross-border production specialization for countries like East Germany and Czechoslovakia, which already had high technical and production standards but had fewer commodities to export to the West; (2) cooperation with a Western partner by means of technical-scientific agreements with the other Eastern Bloc states, including the USSR.

The first option was discussed at the early CMEA meetings, in 1949, and again in 1954, 1956, 1962. Nevertheless, all plans to enhance cross-border automobile production, often detailed plans, remained solely on paper ${ }^{27}$. The only joint project to manufacture an automobile to ever reach the design phase was the cooperation plan between East Germany and Czechoslovakia to produce a $1100 \mathrm{cc}$ model, the "Comecon car". Yet, after almost

\footnotetext{
25 K. E. Weick, Sensemaking in Organizations, London, Sage, 1995, p. 1-65.

26 L. H. Siegelbaum, Cars for Comrades: The Life of the Soviet Automobile, Ithaca, Cornell University Press, 2008, and L. H. Siegelbaum (ed.), The Socialist Car: Automobility in the Eastern Bloc, Ithaca, Cornell University Press, 2011. See also C. Kuhr-Korolev and D. Schlinkert (eds.), Towards Mobility: Varieties of Automobilism in East and West, Hanover, Germany, Volkswagen AG, 2009.

27 B. Ciesla, "Difficult Relations: East German Automobile Production and the Socialist Economic Community", in C. Kuhr-Korolev and D. Schlinkert (eds.), Towards Mobility..., op. cit., p. 87-100.
} 
a decade of negotiations, the cooperation project was terminated by the East German government in 1979, causing considerable damage to both parties involved ${ }^{28}$. According to some German scholars, the failure of the CMEA cooperation project condemned the German Democratic Republic (GDR) - and Czechoslovakia as well - to Fordism in one country, or lame-duck Fordism, due to both the limited markets and an outdated autochthonous product technology ${ }^{29}$.

In these cases, although contracts with foreign firms were limited in scope, it did not mean that engagements with the Western model of mass production of automobiles did not leave their mark on organizational narratives in Czechoslovakia or East Germany. On the contrary, failure and frustration affected the experts' views of the CMEA, while the lack of financial resources to buy ready-to-use technology oriented the socialist manufacturers to more cautious, selective shopping abroad. They had to find alternative sources, rely on second-best technology and substitution or try to reproduce it locally.

At the other end of the spectrum, Eastern Bloc countries that could export commodities to the West - Romania, Poland, and the USSR - did have the resources to buy ready-to-use technology. Licensing agreements and contracts for turnkey plants were the forms that Soviet, Polish and Romanian governments chose to access Western automotive technology in the 1960s and $1970 \mathrm{~s}^{30}$. The deals were various and so were the criteria for choosing Western partners, for example, the existence of pre-socialist relations, the actual financial conditions offered by the partners and their governments, and the highly assertive Eastoriented internationalization strategies of some West European companies, in particular Fiat and Renault ${ }^{31}$. The choice of the partner had important consequences for the technical part of the deal, and contributed to shaping the organizational identities and narratives of host plants. In fact, negotiations for most of the deals began in the late 1950s; most contracts were signed between 1965 and 1971 and covered most of the 1970s.

These were years of change and crisis in the global automotive industry that quickly plunged from the apogee of the Fordist model of production to the first signs of its crisis. At the end of the 1960s, Western manufacturers had basically two options: they could revive the Fordist model by increasing automation, decentralizing production to low-wage areas abroad, and reducing wages at home, or they could increase flexibility and diversify their products $^{32}$. Both Fiat and Renault chose the first option; the CMEA countries were at the time the closest potential markets. Moreover, building turnkey plants offered Renault and Fiat excellent learning opportunities to test

28 T. Vilímek, "Mladoboleslavská Škodovka v období normalizace (1969-1989)”, in O. Tůma and T. Vilímek (eds.), Ceská společnost v 70. a 80. letech: sociální a ekonomické aspekty, Prague, Ústav pro soudobé dějiny, 2012, p. 173-195.

29 W. Abelshauser, "Two Kinds of Fordism: On the Differing Roles of the Automobile Industry in the Development of the Two German States", in H. Shiomi and K. Wada (eds.), Fordism Transformed: The Development of Production Methods in the Automobile Industry, Oxford, Oxford University Press, 1995, p. 270-296, and S. Link, Forging Global Fordism: Nazi Germany, Soviet Russia, and the Contest over the Industrial Order, Princeton, Princeton University Press, 2020.

30 M. Jastrzab and J. Wawrzyniak, "On Two Modernities of the Polish Automotive Industry: The Case of Fabrika Samochodów Osobowych and Its Staff (1948-2011)", Acta Poloniae Historica, n 115, 2017, p. 37-69 and L. Gatejel, "A Socialist-Capitalist Joint Venture: Citroën in Romania during the 1980s", Journal of Transport History, vol. 38, $\mathrm{n}^{\circ}$ 1, 2017, p. 70-87. See also M. Jastrząb, "Fiat's Small Cars for Polish Mass Motorisation: The Small Engine Car Factory in Bielsko-Biała and Tychy, 1971-80", and M. Miljković, "Making Automobiles in Yugoslavia: Fiat Technology in the Crvena Zastava Factory, 1954-1962", Journal of Transport History, vol. 38, n 1, 2017, p. 37-52 and 20-36; J.-L. Loubet, Renault : histoire d'une entreprise, Boulogne-Billancourt, ETAI, 2000, p. 217-220.

31 V. Castronovo, Fiat: 1899-1999: Un secolo di storia italiana, Milan, Rizzoli, 1999.

32 G. Volpato, "The Automobile Industry in Transition: Product, Market Changes and Firm Strategies in the 1970s and 1980s", in S. Tolliday and J. Zeitlin (eds.), Between Fordism and Flexibility: The Automobile Industry and Its Workers, Oxford, Berg, 1992, p. 193-223. 
the introduction of more extensive automation systems.

\section{TWO TRAJECTORIES: ŠKODA AND AVTOVAZ}

The two selected cases, Škoda and AvtoVAZ, stand at opposite extremes of the socialist automobile industry from the perspective of access and use of foreign automotive technology. The Volga plant was built between 1968 and 1971, together with the nearby town of Togliatti. By contrast, the Mladá Boleslav plant was built in 1895 as a bicycle firm called Laurin \& Klement; by 1899, it was producing its first motorcycles, and by 1905 its first cars. The company went through all the relevant phases in the reception and re-working of Fordist organizational practices and technology. The Volga plant was formally a turnkey plant, since Fiat provided product and process technology as well as some of the equipment and technical assistance, ranging from designing to initiating production. On the contrary, the modernization of the Škoda Mladá Boleslav plant took place without any significant input from the West. The Czechoslovaks had to rely on the CMEA and internally produced equipment and supplies. Whereas the Togliatti factory can reasonably be considered a grand technological project, with the construction from scratch of both factory and town in less than five years ${ }^{33}$, Mladá Boleslav was an old factory town and the restructuring of the automobile plant was the result of waves of partial improvements, made with little input from Western technology and mostly scant resources. By contrast, VAZ was meant to become the showcase of the better use the Soviets could make of foreign technology and work organization practices compared to the use made by capitalists. To this aim, over the years, Soviet authorities allocated plenty of resources, both material and intellectual, to improve work productivity and the product quality ${ }^{34}$. In 1984, the launch of the new VAZ model, the Samara, was again the result of cooperation with foreign partners (Porsche, for some of the product technology, and the Italian UTS for process technology).

\subsection{The 1920 s and 1930 s and behind the scenes at Škoda (AZNP) and VAZ}

It is important to stress the substantial differences in how the so-called American model of mass production ${ }^{35}$ was reinterpreted during the 1920s and 1930s by Czechoslovak and Soviet automobile industry engineers. During the 1920s and 1930s, Czechoslovak engineers, citizens of a parliamentary democracy at the time, visited American automobile production facilities. From their reports, it is clear that they were fascinated with the enormous productivity of US factories, but they were also aware that the new production methods and technology had to be adapted to the needs of the Czechoslovak automobile industry ${ }^{36}$.

\footnotetext{
33 P. Josephson, "Projects of the Century in Soviet History: Large-Scale Technologies from Lenin to Gorbachev", Technology and Culture, vol. 36, $\mathrm{n}^{\circ}$ 3, 1995, p. 520, and F. Bellat, Une ville neuve en URSS : Togliatti, Marseille, Parenthèses, 2015.

34 S. Zhuravlev, AvtoVAZ: Mezhdu proshlym i budushchim, Istoriia volzhskogo avtomobil'nogo zavoda 1966-2005, Moscow, Izdatel'stvo RAGS, 2006, and E. Shulzhenko, Reforming the Russian Industrial Workplace, International Management Standards Meet the Soviet Legacy, London, Routledge, 2017.

35 See J. Zeitlin and G. Herrigel (eds.), Americanization and Its Limits: Reworking US Technology and Management in Post-war Europe and Japan, New York, Oxford University Press, 1999.

36 I refer in particular to the travel report of Václav Klement, founder of Škoda (Resumé. Zprávy o studijní cestě gen. rady V. Klementa do Spojených Států, vykonané spolu s Ing. J. Hauserem v době od 8-7 do 5-11-1927 ku zjištění výrobních poměrů v automobilovém prủmyslu americkém) and to the other reports in the Škoda Auto Muzeum, Historical Archives (henceforth ASA), fond ASAP, box 93. I analyzed these reports in detail in V. Fava, The Socialist
} 
Technicians were looking for a way to increase domestic production, raise productivity, while incorporating the long tradition of craftsmanship in Bohemia, preserving and making the most of its highly qualified workforce and of the high standards of its machine-tool industry. In addition, most of the Czechoslovak engineers' travels were organized and funded by the Masaryk Academy of Labour (Masarykova akademie práce $)^{37}$. In their reports, experts often emphasized the negative consequences of applying Taylorist and Fordist practices of work organization - workers' losing their skills and being dehumanized. They preferred a more human-centred vision of scientific management, inspired by the humanitarian socialism of the first Czechoslovak president, Tomáš Masaryk (1850-1937). For this reason, in their search for efficiency, they counterbalanced the new American theories with practices and theories emerging elsewhere in Europe, particularly France and Switzerland ${ }^{38}$.

After the Second World War, between 1946 and 1947, an American engineer, Alexander Taub, visited the Škoda plant and, together with Czechoslovak automotive engineers, presented a project to reconstruct the automobile industry in the country. Škoda's technicians also visited the United States and they left detailed reports revealing their admiration for the American productivity miracle. The reports show a marked discontinuity with the interwar years. Despite calls for adaptation to Czechoslovak traditions, Taub's project was in practice intended to completely revolutionize production plants, techniques, and the organisation of labour that Škoda had relied on up to that point ${ }^{39}$. After the Communist takeover, in late February 1948, with Taub gone, experts saw an opportunity in the envisioned project for economic integration of the socialist countries: their know-how would have given modernized and re-equipped Czechoslovak industry a leadership position in the CMEA division of labour. This was not to be, however, since, after 1949, Soviet advisers prevented Škoda AZNP from modernizing their production facilities, and thus jeopardized the very existence of the Czechoslovak automotive industry.

There is a significant body of literature dealing with Soviet Americanism - starting from Lenin's fascination with scientific management - and the Fordomania that was sweeping the Soviet Union in the 1920s and 1930s. Some of the most important works consider specifically the automotive industry and the Soviet Detroits ${ }^{40}$. Like in Czechoslovakia, Soviet workers and engineers made industrial pilgrimages to America; some of them even graduated from the Henry Ford Trade School in Dearborn, Michigan. Unlike the Czechoslovaks, however, the Soviets had massive access to US and German automotive technology: in 1928-1932, the Ford Motor Company provided production technology, licenses and technical assistance for the construction of the GAZ plant in Nizhny

People's Car: Automobiles, Shortages and Consent in the Czechoslovak Road to Mass Production (1918-1964), Amsterdam, Amsterdam University Press, 2014.

37 J. Janko and E. Těšínská (eds.), Technokracie v Českých zemích (1900-1950), Prague, Archiv AV ČR, 1999.

38 Aša ASAP, 93, Předbežná cestovní zpráva o organisaci závodů ve Švýcarsku. Důvěrné. Organisace výroby.

39 V. Fava, The Socialist People's Car..., op. cit., p. 47-65. I analyzed the travel reports available in the ASA, fond AZNP/P, box 4, in particular, A. Taub, “A People's Technology: A Report to Dr. Ing. F. Fabinger, General Director of KOVO”, Prague, September [1946]; A. Taub, “Zpráva, I. Program vyrobků, II. Závody a zř́zení”, 1947; J. Frei, "Zpráva o prohlídce amerických automobilových a motocyklových závodů v době od 10. do 22. června 1946”; V. Matouš, "Cestovní zprávy z USA, Výtah z cestovních zpráv od 31. srpna do 12. listopadu 1947”; V. Kremar, "Automobilové továrny v USA, Zpráva z cesty konané v červenci-září 1947”.

40 L. H. Siegelbaum, Cars for Comrades..., op. cit.; B. Shpotov, "Ford in Russia, from 1909 to World War II", Y. Cohen, "The Soviet Fordson: Between the Politics of Stalin and the Philosophy of Ford, 1924-1932", J.-J. Chanaron, "Ford in the USSR and Russia: A Third Attempt for Sustainable Success (1989-2003)", in H. Bonin, Y. Lung, and S. Tolliday (eds.), Ford: The European History, vol. 2, Paris, P.L.A.G.E., 2003, p. 505-522, 531-549, 559-579. 
Novgorod (originally NAZ) and the AZLK plant in Moscow ${ }^{41}$. Between 1945 and 1950, the dismantling of automobile plants in the Soviet-occupied sector of Germany led to a massive transfer of automotive technology (mainly multipurpose metalworking equipment) to the USSR ${ }^{42}$. Most of these scholarly works emphasize how the Soviets dealt with technology as a panacea for social and economic problems and how they considered foreign technology and know-how to be a politically neutral weapon against backwardness, massively investing in the construction of giant foreign-equipped plants ${ }^{43}$.

Yet, to foreign observers, the results of these transplants of technology appeared to be heavily influenced by the Soviet perspective and local interpretative peculiarities. Yves Cohen, in an excellent work on the Soviet version of the Fordson tractor (produced at the Red Putilovet Plant between 1924 and 1932), shows the difficulties of the reverse engineering of foreign models, even with US machinery and US-trained workers. Cohen writes that, according to many observers, in the 1930s the Soviets seemed to focus on the most visible aspects of mass production, such as quantity and assembly-line speed, while apparently being less attentive to small requirements, the material interdependence of mass production, and the need to minimize hard manual work ${ }^{44}$. According to Elena Shulzhenko, the 1920s success of a "dehumanizing and mechanistic version of scientific management" was at the basis of the persistent "punitive character of production work practices" and other dysfunctions of Soviet work organization, such as the excessive separation between carrying out work and checking it, the high number of administrative and controlling personnel, and authoritarian control over workers ${ }^{45}$. The decision to build a greenfield factory on the Volga River was an attempt to use foreign technology and work-organization practices to solve the problems of a Soviet industry that by the early 1960s appeared badly and unevenly mechanized, with enormous labour-management problems.

\subsection{The 1960 s and the new impetus of socialist automobile production}

Only between 1960 and 1964 did the AZNP/Škoda plant receive the investments it needed to modernize its obsolete equipment, increase its production from 120 to 600 cars a day, and launch a new model, the $1000 \mathrm{MB}$. The investment was estimated at two billion Czechoslovak crowns (US\$ 280 million) ${ }^{46}$. AZNP, however, had scant financial resources to import components or buy licenses abroad, thus cooperation with capitalist firms was limited to specific parts of the production process $^{47}$.

The analysis of technical narratives about the plant reconstruction shows that in order to design the new plant, the AZNP management had called in the technicians who had participated in missions abroad in the 1920s and 1940s and had drafted the 1947 project. By means of handbooks and documents obtained

\footnotetext{
41 B. Shpotov, "Ford in Russia...", art. cit., p. 516-517.

42 A. I. Miniuk, "The Use of German Industrial and Scientific Technical Potential in the Development of the Soviet Motor Industry, 1945-1950”, in C. Kuhr-Korolev and D. Schlinkert (eds.), Towards Mobility ..., op. cit., p. 73-87.

43 S. Kotkin, Magnetic Mountain: Stalinism as Civilization, Berkeley, University of California Press, 1995.

44 Y. Cohen, "The Soviet Fordson...", art. cit., p.546.

45 E. Shulzhenko, Reforming the Russian Industrial Workplace..., op. cit., p. 20.

46 P. Pavlínek, A Successful Transformation?..., op. cit., p. 69.

47 Technical narratives at Škoda between 1956 and 1968 are reconstructed on the basis of the published memoirs of F. H. Žalud, Přežili jsme, Prague, Trilabit, 1998, and P. Hrdlicka in J. Králík, V soukolí okřidleného šipu: Zákulisí automobilky Škoda očima konstruktéra Favoritu Petra Hrdličky, Prague, Grada, 2008. Other relevant documents are in ASA, fond AZNP, box 26 and 34, and in Ventil, the factory periodical, 1966-1969.
} 
from foreign colleagues, these experts had managed to keep informed about recent developments in the automobile industry throughout the world ${ }^{48}$. Beginning in the late 1950 s, they were again allowed to travel abroad, and thus re-established contacts with representatives and dealers of capitalist automotive companies and suppliers. In their reports, they recall how the US embargo, budget restrictions, and distrust of representatives of a socialist country limited their chances to obtain US machinery and to find capitalist business partners ${ }^{49}$. This forced them either to do it themselves or to contact foreign suppliers who had pre-war relations with Czechoslovakia; most of them were specialized, niche producers from Austria, Switzerland, Germany and Italy $^{50}$. As soon as the political pressure of the 1950 s eased, experts were making reference to the kind of innovativeness that had more in common with the pre-war Škoda tradition than with Soviet modernity ${ }^{51}$.

With the Czechoslovak reform movement in the late $1950 \mathrm{~s}$, most specialists spoke out in favour of liberalization of the domestic market, the introduction of market pricing mechanisms, and autonomy of the enterprise especially in its relations both with suppliers and with internal and foreign dealers. They focused on the need to solve existing problems, especially in export, and to restore efficiency and prestige to the Czechoslovak automobile industry.

On the eve of the Soviet-led military intervention in late August 1968, experts were closely studying marketing and advertising strategies, which they believed to be the key to gaining access to Western markets. They were aware of the changes in the global automobile industry and that West European manufacturers were competing over capacity to deal with large-scale production and, mainly, over their ability to offer changes driven by marketing requirements ${ }^{52}$. Two important initiatives were implemented at Škoda in 1968: the production of two different models of car in the same plant (the 720 and the 740) with a minimum of interchangeable parts and a body by an Italian designer, Giorgetto Giugiaro ${ }^{53}$. This was against the rules of socialist automobile manufacturing - one model at time until obsolescence. The other initiative was to commission an "Analysis of the Image of the Škoda" to a Western German company, Arbeitsgruppe für psychologische Marktanalysen (today, Psyma), in the German Federal Republic ${ }^{54}$.

A comparison with the discussions that took place between Moscow and Turin in the same years gives us an idea on how far the Czechoslovak experts were actually departing from Soviet ideas of automobile manufacturing. The Volga Automobile Plant was built as a result of an agreement signed in May 1966 between Fiat and the Ministries of Automotive Industry and of Foreign Trade of the USSR. The Volga plant had to produce 2000 units of the Fiat 124 daily, a model that had to be easy to use and repair, resistant, useful, and unsophisticated, and it had to be produced according to the canons of pure Fordism ${ }^{55}$.

\footnotetext{
48 F. H. Žalud, Přežili jsme, op. cit., p. 82-83.

49 J. Králík, V soukoli okř́dleného šipu, op. cit., p. 89-101.

50 The list of AZNP's foreign suppliers in the 1960s included Swiss (Oerlikon) and Austrian companies (Klingelnberg; Ebler), and a few British and Italian niche manufacturers, such as Birnec and Fonderpress s.p.a. from the metal machine-manufacturing district around Bologna, and for body design (Giorgetto Giugiaro).

51 Ventil, issues from February 1968 to February 1969.

52 ASA, f. AZNP, box 65.

53 G. Molineri (ed.), Giorgetto Giugiaro: The Genius of Design, Milan, Rizzoli, 2015.

54 ASA, f. AZNP, box 65, and K. Haupt, "Die Entwicklung der psychologischen Marktforschung in Deutschland", Transfer, vol. 24, n 1, 2009, p. 1-10.

55 Archivio Storico Fiat (ASF), Fond URSS, 29; ASF, Fond URSS, 37 "Protocollo di Collaborazione tecnico scientifica nel campo automobilistico", 1 July 1965; ASF, Fond URSS, 37, "Accordo Generale", 15 August 1966. Also W. H. Parker, "The Soviet motor industry", Soviet Studies, vol. XXXII, n 4, 1980, p. 515-541.
} 
Construction of the VAZ plant cost more than US\$ 642 million, which included Fiat licenses and technical assistance as well as equipment from Italy, the United States, France, the United Kingdom, Belgium, Switzerland, and West Germany ${ }^{56}$.

The choice of Fiat as a general contractor is highly significant of what the Soviet authorities wanted to achieve through working with a foreign firm. Soviet Americanism is one key to understanding why the Soviet authorities chose the Italian company. The records of the negotiations with Fiat managers confirm the view of historian Lewis H. Siegelbaum who stresses the Soviet interest in American technology and know-how, which in 1960s was not directly accessible to Soviet experts. It is well known that, at the beginning of the 1960s, both Renault and Volkswagen had started negotiations with the Soviet authorities for the construction of the Volga plant ${ }^{57}$. Despite substantial interventions by the French government, the Soviets ultimately chose Fiat as the general contractor. According to records in the Fiat and Russian archives, the close relationship between the Fiat management and the American government was one of the main reasons for the Soviet decision (besides the financial terms of the deal, which were quite favourable, and Fiat's acceptance of a tight schedule).
Since the 1940s, Fiat had in fact developed trust and cooperation with machinery producers and US assemblers and also with eminent members of the US Administration. Fiat and Russian documents show that Soviet representatives were interested in resuming trade with the United States and were asking the Italians to reassure them that doing business with Fiat would have simplified trade and technological relations with America ${ }^{58}$. The question of the origins of the equipment kept coming up in the Fiat-Soviet negotiations. Russian documents confirm the Soviet interest in using Fiat to obtain the American machinery they had seen on the Mirafiori lines (the main plant of Fiat in Turin) and they considered it a guarantee of success in implementing mass production and a measure of quality ${ }^{59}$.

Automation was another key word in the negotiations ${ }^{60}$. The first contacts between Fiat and Soviet experts had taken place in the second half of the 1950s, after the Soviet Plan made industrial automation a priority and in close connection with the automation efforts of the Soviet industry. Every year from 1955 onwards, delegations of Soviet technicians visited Fiat headquarters in Turin and other Fiat plants and workshops.

The first Fiat delegations sent to the USSR, in 1957, consisted mainly of machinery-production experts' representatives of Fiat Grandi Motori, the machine-tool producer.

\footnotetext{
56 J. Hanen, "La coopération entre la RNUR et l'URSS dans les années 1960-1970”, Renault Histoire, n 48, 2020, p. $67-76$.

57 M. Grieger, "Business with the Socialist Automotive Industry: Volkswagen's Economic Relations with the Soviet Union and the German Democratic Republic", in C. Kuhr-Korolev and D. Schlinkert (eds.), Towards Mobility..., op. cit., p. 102.

58 V. Castronovo, Fiat..., op. cit., p. 1109-1112. The parallel diplomatic relations of Fiat are contextualized and treated extensively in V. Fava, "Between Business Interests and Ideological Marketing: The Soviet Union and the Cold War in Fiat Corporate Strategy (1957-1972)", Journal of Cold War Studies, vol. 20, n 4, 2019, p. $26-64$.

59 S. Zhuravlev, AvtoVAZ..., op. cit., p. 62-63. See also ASF, fond URSS, 29, "Studio di massima per realizzare uno stabilimento plant per la produzione di una vettura di media grandezza nell'URSS", February 1966 and ASF, fond URSS, 34, "Dichiarazione-Complesso produttivo" and "Verbali rapporto URSS”, 13 May 1966; 21 May 1966.

60 Travel reports of Italian technicians to the Soviet Union: ASF, fond URSS, Visite di Viaggio, "Visita Stabilimenti in Russia, Fiat Grandi Motori", 26 July 1957; "Visita in Russia di costruttori italiani di macchine utensili e tessili, invitati dal ministero sovietico dell'industria leggera (Novasider)", July 1957; "Visita in Russia and Viaggio a Mosca, Leningrado e Minsk", 17 October-3 November 1959; "Missione Italconsult in URSS", 10-24 November 1961, in ASF, fond URSS, 27; and "Missione siderurgica italiana 'ASSIDER' nell'Unione Sovietica. Relazione di viaggio", 27 August-9 September 1960.
} 
Fiat representatives saw the chance to export to the USSR the machine tools that its management had imported from the United States in the early 1950s and had since then learned to reproduce (having bought the licenses) and even improve them ${ }^{61}$. East-West trade restrictions, which applied more to American producers than to their European competitors, thus offered European tool-makers, among them Fiat and Fiat suppliers, an opportunity to obtain a competitive advantage on the Soviet market for both their traditional and innovative machines. Fiat was offering the Soviets a well-established and tested industrial model, which had its roots in Fiat's reworking of the American model of mass production after the war, and it was embedded in the Mirafiori plant.

But Fiat was on the verge of significant and radical changes in its leadership and business strategy and was radicalizing its approach to inflexible Fordist automation ${ }^{62}$. This process had begun with the 124 (in 1965) but it was with the 127 (in 1971) that the use of transfers became ubiquitous and Fiat set newer and higher standards of automation ${ }^{63}$. The VAZ provided Fiat with the opportunity to experiment with automatic machines and transfers in different phases of the production process to a degree that would have been unthinkable in Mirafiori, where automatic machines and transfers were only used in some parts of the production process - so-called islands of automation - and their introduction had proceeded at a snail's pace.
Technical reports and interviews with Fiat experts who were in Togliatti suggest that Italian and Soviet experts did indeed share a common technical language. According to one of the Fiat former executives interviewed: "The Soviets would have liked all the machinery coming from the United States; they thought that technology was machinery. They were driven by a sort of idolatry of machines, which Fiat partly shared with them" ${ }^{64}$. Besides their interest in US technology, Soviet technicians admired the Fiat Mirafiori Plant, where the training of Soviet workers and experts took place. Fiat had inaugurated the Mirafiori Plant, designed by Vittorio Bonade Bottino, after visiting the Highland Park Ford Plant designed by Albert Kahn, in May 1939. The Italian press and public opinion presented Mirafiori as the "largest Italian plant", a "colossus" inspired by the utopia of the "push-button factory" 65 . In 1965, Fiat thus offered the Soviets an "exaggerated" version of 1930s American Fordism, the expression of a "cultural dramatization of the technological phenomenon" which technical experts from Fiat shared with their Soviet counterparts; it was also all oriented to the cult of production, which characterized early Fordism and Detroit automation. Vittorio Valletta had led Fiat with the idea that "production comes first", strongly rejecting what he considered the "cult of waste" characterizing the latest forms of Sloanism and flexible mass production ${ }^{66}$. Yet the new factory in Togliatti was considerably larger than Mirafiori, 600 hectares compared to 200 hectares, and its

61 D. Bigazzi, La Grande Fabbrica: Organizzazione aziendale e modello americano alla Fiat dal Lingotto a Mirafiori, Milan, Feltrinelli, 1999, p. 173-183.

62 G. Maielli, "Spot-Welding Technology and the Development of Robotics at Fiat, 1972-1987: A Case of Production Management Discontinuity?", Business History, vol. 47, n 1, January 2005, p. 102-121. On Fiat's business transformation, see V. Comito, La Fiat tra crisi e ristrutturazione, Milan, Editori Riuniti, 1982, p. 57-60, and G. Volpato, Il caso Fiat: Una strategia di riorganizzazione e di rilancio. La Fiat negli anni ottanta e novanta, Turin, UTET, 1996.

63 D. Bigazzi, "Mass Production or 'Organized Craftsmanship'? The Post-War Italian Automobile Industry", in J. Zeitlin and G. Herrigel (eds.), Americanization and its Limits..., op. cit., p. 269-297.

64 Interview of the author with Carlo Mangiarino, Turin, 29 May 2009. Mangiarino was Fiat's “capoprogetto" (project leader) in Togliatti. He was later a member of the board of directors of Ferrari S.p.A. and Chairman of Comau. 65 D. Bigazzi, "Mass Production or Organized Craftmanship", art. cit., p. 284-288.

66 F. Amatori, "Gli uomini del Professore: Strategie, organizzazioni, management alla Fiat tra anni Venti e anni Sessanta", in C. Annibaldi and G. Berta (eds.), Grande impresa e sviluppo italiano, Bologna, Il Mulino, 1999, p. $266-271$. 
monumentality, huge windows, administrative tower, and abundance of aluminium brought to mind, as suggested by historian Fabien Bellat, American skyscrapers and capitalist cathedrals of commerce more than Mirafiori $\operatorname{did}^{67}$. Fiat organizational practices, product designs, and production technologies were reworked considerably - more than $65 \%$ of VAZ parts were modified. On the other hand, the involvement of Fiat in all phases of the technology transfer was unusual by Soviet standards, as was the exchange of personnel between Fiat and the Soviets ${ }^{68}$. Negotiations on most details of the product and process technology took place in the phase preceding the signing of the contract in 1965-1966 and in the phase of the actual construction of the plant from 1967 to $1972^{69}$. The main bones of contention were the model of the car and the modifications recommended to adapt the 124 to Soviet conditions, the lay-out of the plant and the facilities for the workers, as well as the creation of a network of services. In each of these cases, Italians had to confront Soviet preconceptions and modi operandi. The first challenge was to convince Soviet technical experts that the Fiat 124 was the right car for the motorization of the Soviet Union. Technical narratives reveal that there were disagreements not only between Italian and Soviet experts, but also across operational lines: technician-designers on the one hand, executives on the other. It took almost five years to reach an agreement about which model to produce in the new plant.
Dante Giacosa (1905-1996), the designer of many popular Fiats, including the 124, the Topolino, and the 500, and the head of Fiat's Motor Vehicle Technical Management, went to Russia for the first time in 1960, and visited different plants and the Soviet Institute for Automotive Research (Nautchnoissledovatelski Avtomobilny y Avtomotorny Institut, NAMI). A second trip followed in $1965^{70}$. The 1960 trip had an exploratory and diplomatic nature whereas the 1965 visit was already part of the negotiations between Fiat and the Soviet government. The first report provides good evidence of Fiat testing the ground for a deal with the Soviet authorities: Giacosa was, on the one hand, trying to understand the productive conditions, gathering as much information as he could, looking around and talking with the engineers; on the other, he was sending out clear signals of Fiat's openness to possible collaboration in the automotive sector. It seems, however, that both sides still had very confused ideas about the nature of that future collaboration. In his second report, of 8-14 September 1965, Giacosa was praising the Soviet technicians working at NAMI, as he had done in the previous report, but he was also highlighting how popular the study of motorization had become in the Soviet Union. Concerning the choice of the model, he stressed that Soviet customers would handle the car roughly. Furthermore, he underlined the problems that cars faced in the hostile and diverse weather conditions of the country: outdoor parking spaces with a temperature ranging from 50 degrees centigrade in summer to -50 degrees in winter, very bad country roads,

67 F. Bellat, Une ville neuve en URSS..., op. cit. p. 82-85.

68 N. Nettleton, "Driving towards Communist Consumerism", Cahiers du Monde Russe, vol. 47, n 1-2, 2006, p. 131-151.

69 ASF, fond URSS, Visite di Viaggi, "Prima analisi su problemi inerenti la collaborazione automobilistica con l'URSS, 4/4/1965", and "Argomenti del colloquio con l'ing. Gvishiani, 9/9/1965"; see also Russian State Archive of the Economy (Rossiiskii Gosudarstvennyi Arkhiv Ekonomiki-RGAE), fond 398, op.1, d.93, "O komandirovke v Italiiu direktora Moskovskogo avtozavoda im. I.A. Likhacheva tov. Borodina P.D. i glavnogo tekhnologa zavoda tov. Stepashkina S.M. na avtomobil'nye predpriiatiia kontserna 'Fiat's 22-go noiabria po 6-e dekabria 1965 goda", December 1965.

70 ASF, Fondo personale Giacosa, 66/185, "Visita missione tecnica sovietica alla Fiat", 27 May-3 June 1959 and ASF, fond URSS, 34, "Note sul Viaggio in Russia", 8-14 September 1965. For more extensive consideration, see D. Giacosa, I miei primi quarant'anni di progettazione alla Fiat, Milan, Automobilia, 1979, p. 369-438 (or the English edition: Forty Years of Design with Fiat, Milan, Automobilia, 1979). 
poor service, and, outside the towns, no hope of finding nearby gas stations. He was also truly worried about the expectations of NAMI experts who "would be deceived if we offered them a traditional car" 71 . He was thus trying to convince them that the car best suited to the local weather conditions, infrastructure, lack of service stations and scarcity of spare parts, as well as the few gas stations, was a medium-sized car, similar to the one that Fiat was selling to Poland and Romania. On behalf of Fiat, his official suggestion was to produce a 1300, a traditional car, with a front engine and rear-wheel drive that was easy to repair and did not need a good network of service stations. What Fiat suggested, however, was not favoured by the NAMI experts. Giacosa found them "as passionate as the Romanian and Yugoslav technicians for Western technical journals" about the most modern and appealing advances in technology (front engine, frontwheel drive, aluminium chassis) or cars like the BMC Mini-Minor, the Renault 16 (R16), the Autobianchi Primula, the Peugeot 204, and the Škoda 1000. According to him, NAMI engineers were arguing that, since production was planned for 1971, they wanted to have the most modern devices at their disposal ${ }^{72}$. The Soviets would have preferred a front-wheeldrive car like the Autobianchi Primula rather than the traditional rear-wheel drive of the 124 . In this regard, Giacosa wrote in his memoirs that he did not disagree with the NAMI experts but that Valletta, Fiat's President, had imposed the 124 for practical and commercial reasons: the 124 had rolled off the Mirafiori assembly line shortly before the agreement was signed, and was a very traditional car, imitative of American models, designed to meet the growing European demand for a low-cost car that had to be larger and more powerful than traditional Fiat models but not too expensive and not as sophisticated as other Italian medium-power cars like the Alfa Romeo or Lancia.
A similar disagreement also appears in the Russian archive records. Whereas the technicians originally seemed to have preferred the solutions employed in the Moskvich modernization plan and the use of local technology, and later the Primula, Aleksey Tarasov, the minister of the automotive industry, and Viktor Poliakov, the VAZ director, were decidedly more inclined to reach an agreement with Turin and to give preference to modernization of production and simplicity rather than to innovativeness of $\operatorname{product}^{73}$.

\subsection{The 1980s: Adapting to Global Industry: Favorit and Samara ${ }^{74}$}

A decade later, both enterprises were going through a new wave of product and process modernization. The last fifteen years of the history of Škoda and VAZ as communist enterprises (1974-1989) are highly relevant to this article because of the gradual opening up of CMEA countries to foreign direct investment, the tentative extension of Western multinationals' production networks to Eastern Europe, and the emergence of a superior Japanese production model.

After the 1968 Soviet-led military intervention and during the reinstitution of hardline Communist policy (called normalizace) in 1970s Czechoslovakia, politics and secret police were present in the Mladá Boleslav factory as never before: for having backed reform, many managers and experts were removed from their positions or had left the country and the StB (secret police) kept a close watch on the implementation of decision-making and the political climate at the factory. Contacts with foreign experts and contracts with capitalist firms became the subjects of investigation, and more than one AZNP director was investigated

71 D. Giacosa, I miei primi quarant'anni..., op. cit., p. 414.

72 D. Giacosa, I miei primi quarant'anni..., op. cit., p.418.

73 V. Berezyn, Poliakov, Moscow, Molodaia Gvardia, 2007.

74 This part of the research is still in progress, so these observations are only preliminary. 
for his allegedly anti-socialist activities. In the meantime, resources were being wasted in failed joint ventures with the GDR from 1972 to 1979 and the USSR in $1977^{75}$. In the 1980s, the Czechoslovak economy worsened and the many attempts at reform could not relieve the planned economy of its agony. Technical narratives and experts' memoirs describe the many measures implemented by Škoda technicians and managers to avoid production shutdowns. A buzzword became "production at any cost": failures in the CMEA and in domestic supply forced them to buy components and parts from the West and to intervene only partly in dealing with the ageing production equipment (for instance, assembly line and body work restyling in 1975-1976) ${ }^{76}$. In the 1980s, the collapse of the CMEA and internal demand for cars made it more urgent to provide a new car model that could be exported to the West. Between 1982 and 1987, 4500 million Czechoslovak crowns (the equivalent then of US\$ 422 million) were spent by the Czechoslovak government to buy new technology, licenses and parts for the new Škoda model, the Favorit. Only the direct and most important suppliers had access to Western technologies. Some of this technology came from Western companies like Stile Bertone, John Brown Automation, Girling, Pierburg, Porsche and Boge. Despite the substantial increase of imports from the West, the Czechoslovak industry - which in 1980 imported only $10 \%$ of its components - remained, compared to other Eastern Bloc enterprises, one of the more independent of Western technology ${ }^{77}$.

By contrast, the launch of the new VAZ model, the Samara, in 1984, was again the result of collaboration with foreign partners.
After VAZ, the Soviets signed other deals with Western partners, which provided product and process engineering for models partly designed by Soviet experts. In the 1970s and early 1980 s, Soviet interest in exporting cars to Western and developing countries became stronger. The Soviets aimed at countertrade or buy-back agreements or both, in order to pay for technology and technical assistance and to distribute their products. The low quality of Soviet automotive products and the risks associated with Soviet commercial behaviour discouraged West European firms from committing to forms of production integration with the USSR ${ }^{78}$. In the meantime, the usual distortions of the planned economy emerged in Togliatti - low labour productivity, high turnover, defective parts. Research on the 1980 s is still in progress, but from a preliminary examination of the sources, it is fair to say that despite a gradual convergence in work and factory organization, and similar responses to the problems of planned economy, differences in the Czechoslovak and Soviet experts' understanding and use of Western organizational and technological knowledge persisted at both the factory and the ministerial level. In both cases, experts were aware of the need for foreign technology and technical assistance, but Soviet experts were ambivalent and their attitude was exploitative. VAZ had access to up-to-date technology in 1966 and again in 1979, but it never became independent of foreign suppliers and technology.

\section{CONCLUSION}

As a conclusion, it seems possible to argue not only that CMEA automobile manufacturers

\footnotetext{
75 T. Vilímek and V. Fava, "The Czechoslovak Automotive Industry and the Launch of a New Model: The Škoda Factory in Mladá Boleslav, in the 1970s and 1980s", Journal of Transport History, vol. 38, n 1, 2017, p. 53-69; M. Kopeček (ed.), Architekti dlouhé změny: Expertni kořeny postsocialismu v Československu (1980-1995), Prague, Argo, 2019.

76 T. Vilímek and V. Fava, "The Czechoslovak Automotive Industry...”, art. cit., p. 65.

77 P. Pavlínek, Successful Transformation?..., op. cit, p. 69.

78 ASF, fond Ghidella, 183/5/1. V. Fava, "Italian Companies' Strategies for the Soviet Market: the 1980s and the Challenging Path from Techno-scientific Cooperation to Productive Integration”, Unpublished Manuscript.
} 
followed different trajectories, and had at their disposal unequal resources to obtain Western technology, but also that there were significant differences in Czechoslovak and Soviet experts' understanding and use of Western organizational and technological knowledge at both the factory and the ministerial level, despite Communist ideology and the planned economy. The differences had their roots in the approaches that the Czechoslovak and Russian experts took to scientific management and the American model of mass production. In fact, memories of the "industrial pilgrimages" of the 1920 s permeated the experts' narratives until at least the mid-1960s and informed their vision of the future of the national industry. In the 1960s, the disparity between the Czechoslovak and Soviet automotive industries was evident. Technical and travel reports show a distinct awareness of the conditions and prospects of the global automotive industry. Whereas the Soviet experts considered the introduction of automation and increased productivity, or the search for the most innovative model, to be the preconditions for modernizing the industry, the Czechoslovak experts in the 1960s carefully studied the changes in the ways in which Western automakers were dealing with their increasingly saturated markets and with innovations in product and process technology as well as in marketing and distribution strategies. On the eve of the regime changes beginning in late 1989, Škoda and VAZ were both in critical condition, facing shortages caused by disruptions in production. Both plants needed further investment but experts' expectations of collaboration with foreign partners were different.

This suggests an important aspect that historians should consider - namely, the transfer of Western technology to the Soviet Union and CMEA member states was not as easy and straightforward as scholars have long $\operatorname{argued}^{79}$. Both managerial experts and technicians were not passive recipients of knowledge and technical equipment. Inside the shell of the planned economy, they negotiated and suggested solutions, built opportunities, and fought for what they believed to be best for their national enterprises. They were equals when dealing with Western experts and they managed in part to influence, if not the enterprise's strategy, at least the decision-making on product and process technology, their narratives contributed to the creation of an organizational identity which partially survived the Communist regimes, and may have contributed to create a set of idiosyncratic resources. Business historians should probably focus their attention on whether these expectations and resources did indeed play a role in the post-socialist history of the two factories, and also on if and how these narratives have been used by political decision-makers and post-socialist owners to envision and recreate a post-socialist organizational identity for these enterprises.

\footnotetext{
79 A. C. Sutton, Western Technology and Soviet Economic Development, 1917-1930, Stanford, Hoover Institution on War, Revolution and Peace, 1968; Western Technology and Soviet Economic Development, 1930-1945, 1971, and Western Technology and Soviet Economic Development, 1945-1965, 1973.
} 